\title{
PENINGKATAN KOMPETENSI SISWA PADA MATERI TATA SURYA MELALUI MODEL DISCOVERY LEARNING DALAM PEMBELAJARAN IPA KELAS IX SMPN 2 CANDUNG
}

\author{
Fitra Netti \\ SMP Negeri 2 Candung Kabupaten Agam \\ fitranetti.cdg@gmail.com
}

\begin{abstract}
The research is classroom action research by applying the model of Discovery Learning, which aims to improve the competence of students on the Solar System lesson in natural science learning in ninth grade. This study was conducted in two cycles. Each cycle consists of three face to face. Each four sessions consists of planning, action, observation and test. Based on data analysis is seen an increase in the competence affective, psychomotor and cognitive of student from the first cycle to the second cycle. Based on the results of this research is concluded that there was an increase in student learning outcomes. So it can be ascertained that the Discovery Learning model is appropriate to be implemented in order to improve the competence of students.
\end{abstract}

Keywords : Competence, Discovery Learning, Solar System

\section{PENDAHULUAN}

Ilmu Pengetahuan Alam(IPA) berkaitan dengan cara mencari tahu tentang alam secara sistematis, sehingga IPA bukan hanya pengusaan kumpulan pengetahuan yang berupa faktafakta, konsep-konsep, atau prinsip-prinsip dan prosedur saja tapi merupakan suatu proses penemuan. Pembelajaran IPA diharapkan dapat menjadi wahana bagi siswa untuk mempelajari diri sendiri dan alam semesta, serta dapat menerapkan dalam kehidupan sehari-hari. Prosses pembelajaran IPA menekankan pada pemberian pengalaman langsung untuk mengembangkan kompetensi agar siswa memahami alam sekitar secara ilmiah.

Menurut Noeraida, dkk (2016:6) menyatakan: "bahwa IPA terdiri dari tiga komponen, yaitu sikap ilmiah, proses ilmiah, dan produk ilmiah. Jadi pada hakikatnya IPA merupakan pembelajaran yang didapat dengan cara mencari tahu tentang alam secara sistematis melalui sikap dan proses ilmiah untuk memperoleh produk yang juga bersifat ilmiah.

Pembelajaran IPA diarahkan untuk inkuiri dan berbuat sehingga dapat membantu siswa untuk memperoleh pemahaman yang lebih mendalam tentang alam sekitar. Namun kenyataan yang ditemui oleh siswa kelas IX SMPN 2 Candung dari tahun ke tahun pada materi Tata Surya selalu mengalami kesulitan dalam memahami materi sehingga hasil belajar siswa rendah. Berdasarkan hasil observasi awal, nilai ra- ta-rata ulangan harian dan ketuntasan siswa kelas IX pada materi Tata Surya berada di bawah KKM (Kriteria Ketuntasan Minimal) yaitu 65.

Hasil belajar siswa pada kompetensi psikomotor juga rendah hal ini dapat ditandai dengan kurangnya kemampuan siswa dalam mengkomunikasikan hasil diskusi, kurangnya kemampuan siswa dalam mencari informasi secara cepat. Rendahnya kompetensi afektif, ditandai dengan kurangnya kemampuan siswa dalam bertanya dan menjawab dengan kalimat yang sopan dan lancar serta kurangnya kerja sama dengan teman.

Berdasarkan uraian di atas maka, permasalahan dalam pembelajaran IPA di kelas IX SMPN 2 Candung antara lain: (1) Rendahnya kompetensi (kognitif, psikomotor dan afektif) siswa. (2) Guru mendominasi pembelajaran, guru beranggapan selesai materi lebih penting daripada bagaimana siswa mendapatkan materi tersebut. (3) Siswa kurang memahami pelajaran, kurang kreatif, tidak mampu menghimpun informasi, mengidentifikasi, mengintegrasikan, memverifikasi, dan menarik kesimpulan.

Berdasarkan masalah yang ditemui di kelas, salah satu penyebab rendahnya kompetensi siswa adalah karena strategi yang digunakan oleh guru tidak menantang siswa untuk aktif dan kreatif. Metode yang digunakan oleh guru kurang menarik dan tidak bervariasi. Proses pembelajaran lebih menekankan pada teacher center sehingga siswa berperan sebagai 
pendengar tanpa berbuat sehingga siswa merasa bosan dan tidak termotivasi untuk terlibat dalam proses pembelajaran. Bila kondisi pembelajaran ini dibiarkan berlarut-larut maka akan berakibat buruk pada hasil belajar siswa yang akhirnya mutu pembelajaran IPA di SMPN 2 Candung akan rendah sehingga tujuan pendidikan nasional tidak akan tercapai.

Berdasarkan masalah yang ditemui di SMPN 2 Candung, maka guru perlu melakukan evaluasi terhadap proses pembelajaran dan mencarikan solusinya. Solusi yang dilakukan oleh guru adalah dengan menerapkan model pembelajaran yang kreatif dan interaktif. Model pembelajaran yang diterapkan untuk mengatasi masalah, dalam penelitian ini adalah model Discovery Learning. Model Discovery Learning dipilh dalam penelitian ini karena memiliki kelebihan diantaranya: (1) lebih menekankan pada ditemukannya konsep atau prinsip yang sebelumnya tidak diketahui, (2) bahan ajar tidak disajikan dalam bentuk akhir, (3) siswa dituntut untuk melakukan berbagai kegiatan menghimpun informasi, membandingkan, mengkategorikan, menganalisis, menginteg-rasikan, mereorganisasikan serta membuat kesimpulan.

Model pembelajaran Discovery Learning mengarahkan siswa untuk memahami konsep, arti, dan hubungan, melalui proses intuitif dan akhirnya sampai pada suatu kesimpulan. Penggunaan Discovery Learning, ingin mengubah kondisi belajar yang pasif menjadi aktif dan kreatif, mengubah modus ekspositori ke modus discovery. Tujuan Discovery Learning adalah agar guru memberikan kesempatan kepada siswa untuk menjadi seorang problem solver, seorang scientist, historian, atau ahli matematika.

Kompetensi siswa yang harus dimiliki selama proses dan sesudah pembelajaran adalah kemampuan kognitif (pemahaman, penalaran, aplikasi, analisis, dan pemecahan masalah), kemampuan afektif (kemampuan bertanya, menjawab, dan kerjasama), dan kemampuan psikomotorik (mengumpulkan informasi, membuat pertanyaan, dan presentasi).

Menurut Fadiawati, dkk (2007:40). Pada kemampuan psikomotor, siswa ditantang untuk memecahkan masalah dan menampilkan hasil kerjanya. Kemampuan siswa mengkomunikasikan hasil pemecahan masalah dapat dilihat dalam kejelasan dalam berkomunikasi dan percaya diri dalam berkomunikasi. Hasil belajar ranah kognitif berorientasi pada kemampuan berpikir, mencakup kemampuan yang lebih sederhana hingga kemampuan untuk memecahkan masalah. Aspek yang dapat dilihat pada ranah kognitif menurut Haryani, $\operatorname{dkk}(2007: 14)$ adalah bagaimana siswa menggunakan keterampilan berpikir dan daya nalarnya untuk membuat inferensi serta memecahkan masalah. Hasil belajar ranah afektif berhubungan dengan perasaan, emosi yang menunjukkan penerimaan atau penolakan terhadap sesuatu. Menurut Haryani, dkk (2007:15) aspek sikap dalam belajar akan mempengaruhi prilaku siswa dalam belajar. Kemampuan atau kompotensi menurut Munandar(2010:17) merupakan daya untuk melakukan suatu tindakan sebagai hasil dari pembawaan dan latihan.

Materi yang diambil dalam penelitian ini adalah Tata surya. Tata surya adalah susunan benda-benda langit yang terdiri atas matahari sebagai pusatnya dan planet-planet, meteorid, komet, serta asteroid yang mengelilingi matahari. Teori yang beranggapan bahwa matahari sebagai pusat tata surya disebut heliosentris. Susunan tata surya terdiri atas matahari, planetplanet, satelit-satelit pengiring planet, komet, asteroid, dan meteorid.(Kanginan, 2002:196).

International Astonomical Union pada tahun 2006 mengelompokkan anggota Tata Surya menjadi tiga yaitu: (1) planet, (2) planet-planet kerdil, (3) serta benda-benda Tata Surya kecil. Sebuah benda langit dikatakan planet jika memenuhi kriteria sebagai berikut: (1) mengorbit Matahari, (2) bentuknya cenderung bulat, dalam orbitnya tidak ditemukan benda angkasa lain. Berdasarkan kriteria tersebut anggota Tata Surya yang memenuhi definisi planet adalah 8 planet yang sudah dikenal selama ini yaitu: Merkurius, Venus, Bumi, Mars, Yupiter, Saturnus, Uranus, dan Neptunus (Maulana, 2016:197)

Rumusan masalah dalam dalam penelitian ini adalah: Bagaimana meningkatkan kompetensi siswa pada materi Tata Surya melalui model Discovery Learning dalam pembelajaran IPA kelas IX SMPN 2 Candung?

\section{METODE PENELITIAN}

Jenis penelitian yang dilakukan adalah penelitian tindakan kelas (Classroom Action Research). Arikunto (2006:2) menyatakan, bahwa penelitian tindakan kelas merupakan suatu pencermatan terhadap kegiatan belajar berupa sebuah tindakan yang sengaja dimunculkan dan terjadi dalam sebuah kelas secara bersama. Penelitian dilakukan di SMPN 2 Candung Kabupa- 
ten Agam. Subjek penelitian ini adalah siswa kelas IX SMPN 2 Candung tahun pelajaran 2016/2017 yang menggunakan kurikulum KTSP. Jumlah siswa 31 orang, yang terdiri dari 13 orang laki-laki dan 18 orang siswa perempuan. Penelitian dilaksanakan pada semester genap tahun ajaran 2016/2017, dimulai pada awal bulan Januari sampai akhir Januari 2017. Materi pada penelitian ini adalah Tata Surya.

Desain penelitian tindakan kelas yang dilakukan adalah model yang dikembangkan oleh Kemmis \& Taggart (Arikunto, 2006:16) tiap satu siklus terdiri dari empat tahap, yaitu: perencanaan (planning), tindakan (acting), observasi (observing), dan refleksi (reflecting).

Pada perencanaan dilakukan:

Merancang Rencana Pelaksanaan Pembelajaran (RPP) yang mencirikan pembelajaran Discovey Learning, (2) mendesain rubrik penilaian untuk aspek afektif dan psikomotor siswa, (3) mendesain lembar penilaian berupa tes tertulis berbentuk objektif untuk mengukur aspek kognitif siswa, (4) menyiapkan lembar observasi kegiatan guru, (5) menyiapkan catatan lapangan untuk setiap kali pertemuan.

Pelaksanaan tindakan yang akan dilakukan dalam proses pembelajaran adalah dengan menggunakan sintak yang terdapat pada model Discovery Learning yang terdiri dari enam langkah yaitu: (1) Pemberian rangsangan (stimulation), (2) Identifikasi masalah(Problem Statement), (3) Pengumpulan data(Data collection), (4) Pengolahan data(data processing), (5) Pembuktian(Verification), dan (6) Menarik kesimpulan(Generalization). Kegiatan pada siklus I dilaksanakan tiga kali pertemuan. Pertemuan 1 sampai 2 pada setiap siklus adalah pelaksanaan proses pembelajaran, sedangkan pada pertemuan ke 3 setiap siklusnya diadakan ulangan harian.

Kegiatan observasi dilakukan terhadap proses pembelajaran melalui pengamatan oleh guru IPA. Objek yang diamati meliputi aktivitas guru dan perkembangan kompetensi siswa selama pelaksanaan pembelajaran. Pengamatan terhadap guru yaitu dalam menerapkan skenario pembelajaran dengan model Discovery Learning yang terdiri dari enam tahap.

Pengamatan terhadap siswa dilakukan dengan menggunakan lembaran penilaian kompetensi afektif dan psikomotor. Penilaian kompetensi afektif terdiri dari tiga indikator yaitu: bertanya, menjawab, dan kerjasama. Penilaian terhadap kompetensi psikomotor terdiri dari tiga indikator yaitu: mengumpulkan informasi yang relevan, menuliskan jawaban permasalahan dan mempresentasikan hasil diskusi.

Untuk mengetahui hasil pembelajaran pada aspek kognitif dilakukan tes tertulis berbentuk objektif tes. Tes tertulis atau ulangan harian dilakukan pada pertemuan ke tiga atau di pertemuan akhir setiap siklus. Pada tahap refleksi dikumpulkan semua data yang memberikan informasi mengenai perkembangan pembelajaran. Permasalahan dan perkembangan yang terjadi dianalisis. Dari hasil analisis diperoleh kelemahan-kelemahan atau pelaksanaan tindakan yang masih belum terlaksana sesuai dengan rencana. Kelemahan-kelemahan tersebut diperbaiki pada siklus berikutnya. Dari refleksi tersebut dapat diketahui apa yang telah dicapai dan apa yang belum tercapai atau kelemahan apa saja yang harus diperbaiki.

Instrumen pengumpul data hasil penelitian ini adalah dalam bentuk lembar observasi, tes, dan catatan lapangan. Data hasil pembelajaran aspek kognitif siswa dianalis dengan rumus panduan ketuntasan belajar. Ketuntasan belajar pada aspek kognitif dan psikomotor mengacu pada KKM yaitu sebesar 75 . Data hasil pembelajaran aspek afektif dan psikomotor siswa dinilai dengan menggunakan skala penilaian. Rubrik untuk kompetensi afektif dan psikomotor di buat berdasarkan indikator. Indikator kompetensi afektif terdiri dari: (1) bertanya, (2) menjawab mengacu pada kelancaran dan kesopanan, dan (3) indikator kerjasama mengacu pada kerjasama yang baik, kurang, dan tidak baik. Indikator psikomotor terdiri dari: (1) kemampuan mengumpulkan informasi dari berbagai buku sumber, (2) membuat pertanyaan dan mempresentasikan hasil diskusi. Rubriknya dibuat mengacu pada mampu, kurang mampu ,dan tidak mampunya siswa melakukan.

Indikator keberhasilan kompetensi afektif, psikomotor dan kognitif adalah dengan melihat presentase ketuntasan siswa secara klasikal yaitu minimal $78 \%$ siswa telah tuntas. Jika sudah mencapai ketuntasan secara klasikal 78\%, maka penelitian sudah dapat dikatakan berhasil dan dapat dihentikan.

\section{HASIL DAN PEMBAHASAN}

\section{Hasil Penelitian}

\section{Hasil Penelitian Siklus I}

Hasil penelitian pada siklus I terdiri dari tiga bagian yaitu: penilaian pada kompetensi 
aspek afektif, psikomotor dan kognitif. Pengamatan terhadap kompetensi afektif siswa dilakukan selama proses pembelajaran pada siklus I. Kompetensi afektif yang diamati terdiri dari tiga indikator yaitu: kompetensi bertanya, menjawab, dan kerjasama. Untuk lebih jelasnya perkembangan kompetensi afektif siswa selama pelaksanaan pembelajaran di siklus I dapat dilihat pada Tabel 1 .

Tabel 1. Persentase Kompetensi Afektif Siswa tiap Indikator pada Siklus I

\begin{tabular}{ccccc}
\hline No & $\begin{array}{c}\text { Indikator } \\
\text { Kompetensi } \\
\text { Afektif }\end{array}$ & $\begin{array}{c}\text { \% Kompe- } \\
\text { tensi pada } \\
\text { Pertemuan } \\
\text { ke }\end{array}$ & $\begin{array}{c}\text { \% Rata-rata } \\
\text { Kompetensi } \\
\text { Afektif }\end{array}$ \\
\cline { 3 - 5 } & & $\mathrm{I}$ & $\mathrm{II}$ & \\
\hline 1 & $\mathrm{~A}_{1}$ & 64,5 & 79,6 & 72,05 \\
2 & $\mathrm{~A}_{2}$ & 61,3 & 66,7 & 64,0 \\
4 & $\mathrm{~A}_{3}$ & 86,0 & 86,0 & 86,0 \\
& Rata-rata & 70,6 & 78,5 & 74,6 \\
\hline
\end{tabular}

Keterangan: $\mathrm{A}_{1}=$ bertanya, $\mathrm{A}_{2}=$ menjawab, $\mathrm{A}_{3}=$ kerjasama

Peningkatan kompetensi afektif siswa pada siklus I dapat dilihat dalam bentuk grafik pada Gambar 1.

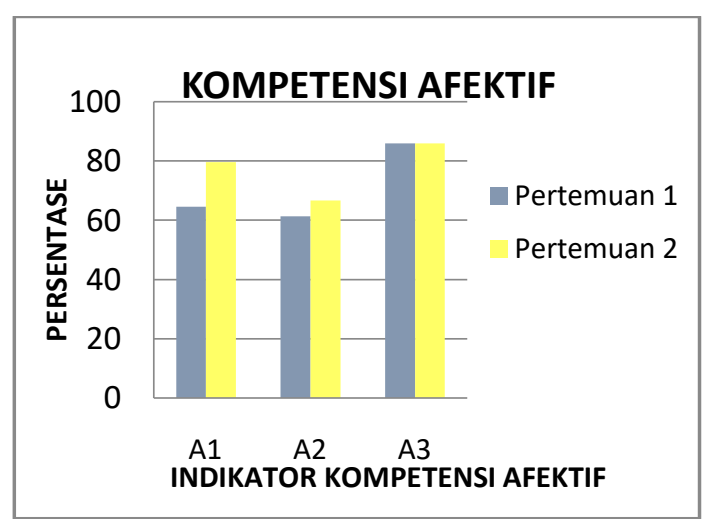

Gambar 1. Persentase Kompetensi Afektif Siswa Tiap Indikator pada Siklus I

Berdasarkan Tabel 1 dan Gambar 1 terlihat adanya peningkatan kompetensi afektif siswa dari pertemuan 1 sampai pertemuan 2 . Ada yang meningkat tajam dan ada juga yang mengalami peningkatan sedikit. Kompetensi afektif siswa yang meningkat tajam adalah kompetensi bertanya, sedangkan meningkat sedikit adalah kompetensi menjawab, dan untuk kompetensi kerja sama tetap, karena kerjasama dalam kelompok sudah baik dari awal.

Pengamatan terhadap kompetensi pskomotor pada siklus I, terdiri dari tiga indikator yaitu: mengumpulkan informasi dari berbagai buku sumber, membuat pertanyaan dan mempresentasikan hasil diskusi. Untuk lebih jelasnya perkembangan kompetensi psikomotor siswa selama pelaksanaan pembelajaran di siklus I dapat dilihat pada pada Tabel 2.

Tabel 2. Persentase Kompetensi Psikomotor Siswa Tiap Indikator pada Siklus I

\begin{tabular}{|c|c|c|c|c|}
\hline \multirow[t]{2}{*}{ No } & \multirow{2}{*}{$\begin{array}{c}\text { Indikator } \\
\text { Kompeten- } \\
\text { si Psiko- } \\
\text { motor }\end{array}$} & \multicolumn{2}{|c|}{$\begin{array}{c}\% \text { Kompetensi } \\
\text { pada Perte- } \\
\text { muan ke }\end{array}$} & \multirow{2}{*}{$\begin{array}{c}\% \text { Rata- } \\
\text { rata } \\
\text { Kompeten- } \\
\text { si } \\
\text { Psikomo- } \\
\text { tor }\end{array}$} \\
\hline & & I & II & \\
\hline 1 & Ps. 1 & 67,7 & 82,8 & 75,3 \\
\hline 2 & Ps. 2 & 74,2 & 76,3 & 75,3 \\
\hline \multirow[t]{2}{*}{3} & Ps. 3 & 75,3 & 78,5 & 76,9 \\
\hline & Rata-rata & 72,4 & 80,3 & 76,4 \\
\hline
\end{tabular}

Keterangan: Ps. $1=$ mengumpulkan informasi dari berbagai buku sumber, Ps. $2=$ membuat pertanyaan, Ps. 3 = mempresentasikan hasil diskusi.

Untuk lebih jelasnya peningkatan kompetensi psikomotor siswa pada siklus I dapat dilihat dalam bentuk grafik pada Gambar 2 .

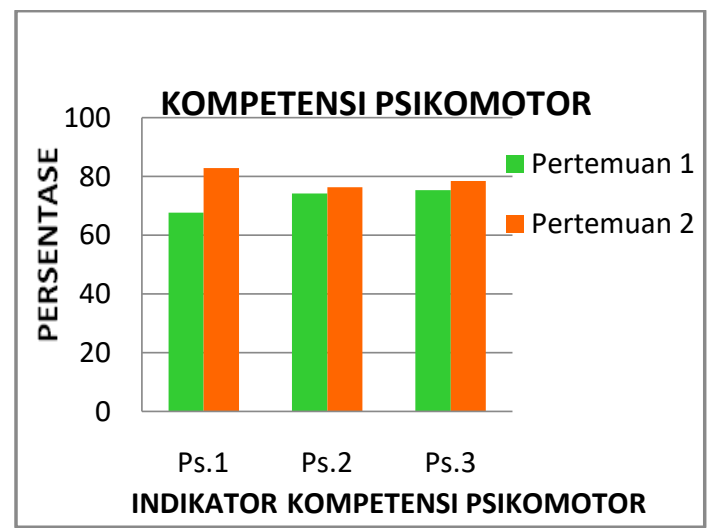

Gambar 2. Persentase Kompetensi Psikomotor SiswaTiap Indikator pada Siklus I

Berdasarkan Tabel 2 dan Gambar 2, terlihat ada yang meningkat tajam dan ada yang sedikit. Persentase yang meningkat tajam adalah pada indikator mengumpulkan informasi dari berbagai buku sumber.

Data tentang kompetensi kognitif siswa pada siklus I diperoleh dengan mengadakan Ulangan Harian I berupa tes tertulis yang diikuti 
oleh 31 orang siswa dengan jumlah soal 20 butir berbentuk objektif tes. Hasil nilai kompetensi kognitif pada siklus I dapat dilihat pada lampiran. Hasil analisis data secara ringkas dapat dilihat pada Tabel 3.

Tabel 3. Persentase Ketuntasan Kompetensi Kognitif dan Nilai Rata-rata Siswa pada Siklus I

\begin{tabular}{ccccc}
\hline \multicolumn{2}{c}{\begin{tabular}{c} 
Siswa yang \\
\multicolumn{2}{c}{ Tuntas }
\end{tabular}} & \multicolumn{2}{c}{$\begin{array}{c}\text { Siswa yang } \\
\text { Tidak Tuntas }\end{array}$} & $\begin{array}{c}\text { Nilai } \\
\text { rata-rata }\end{array}$ \\
\hline $\mathrm{f}$ & $\%$ & $\mathrm{f}$ & $\%$ & \\
25 & 80,6 & 6 & 19,4 & 78,2 \\
\hline
\end{tabular}

Dari Tabel 3 dapat dilihat bahwa dari 31 orang siswa, 25 orang sudah sedangkan 6 orang belum tuntas atau belum mencapai KKM. Yang belum mencapai KKM diadakan remedial sedangkan yang sudah mencapai KKM diadakan pengayaan. Ketuntasan secara klasikal adalah 85 $\%$, berarti secara klasikal siswa belum tuntas.

\section{Hasil Penelitian Siklus II}

Hasil penelitian pada siklus II sama dengan siklus I yang terdiri dari tiga bagian yaitu: penilaian pada kompetensi afektif, psikomotor dan kognitif. Indikator kompetensi afektif yang diamati juga sama dengan siklus I. Untuk lebih jelasnya perkembangan kompetensi afektif siswa selama pelaksanaan pembelajaran di siklus II dapat dilihat pada Tabel 4.

Tabel 4. Persentase Kompetensi Afektif Siswa Tiap Indikator pada Siklus II

\begin{tabular}{|c|c|c|c|c|}
\hline \multirow[t]{2}{*}{ No } & \multirow[t]{2}{*}{$\begin{array}{c}\text { Indikator } \\
\text { Kompetensi } \\
\text { Afektif }\end{array}$} & \multicolumn{2}{|c|}{$\begin{array}{c}\text { \% Kompe- } \\
\text { tensi yang } \\
\text { Dicapai pada } \\
\text { Pertemuan } \\
\text { ke }\end{array}$} & \multirow[t]{2}{*}{$\begin{array}{l}\text { \% Rata- } \\
\text { rata } \\
\text { Kompe- } \\
\text { tensi Afek- } \\
\text { tif }\end{array}$} \\
\hline & & I & II & \\
\hline 1 & $\mathrm{~A}_{1}$ & 84,9 & 92,5 & 88,7 \\
\hline 2 & $\mathrm{~A}_{2}$ & 69,9 & 68,9 & 69,4 \\
\hline \multirow[t]{2}{*}{3} & $\mathrm{~A}_{3}$ & 87,1 & 91,4 & 89,3 \\
\hline & Rata-rata & 81,7 & 85,3 & 83,5 \\
\hline
\end{tabular}

Untuk lebih jelasnya peningkatan kompetensi afektif siswa pada siklus II dapat dilihat dalam bentuk grafik pada Gambar 3 .

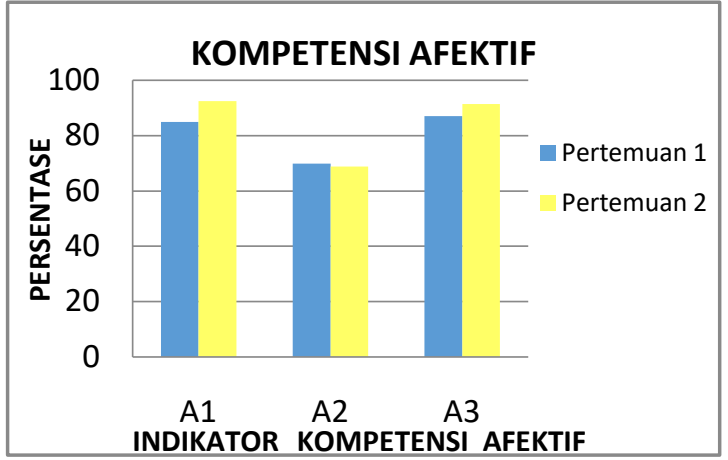

Gambar 3. Persentase Kompetensi Afektif Siswa Tiap Indikator pada Siklus II

Berdasarkan Tabel 4 dan Gambar 3, terlihat indikator A1 dan A3 mengalami peningkatan, sedangkan indikator A2 mengalami penurunan. Ini disebabkan karena siswa kurang memahami materi yang sedang dipelajari dan sebagian siswa menjawab dengan emosi atau kurang sopan.

Pengamatan terhadap kompetensi psikomotor siswa dilakukan selama proses pembelajaran pada siklus II. Kompetensi psikomotor yang diamati sama dengan siklus I. Untuk lebih jelasnya perkembangan kompetensi psikomotor siswa selama pelaksanaan pembelajaran di siklus II dapat dilihat pada pada Tabel 5.

Tabel 5 Persentase Kompetensi Psikomotor Siswa Tiap Indikator pada Siklus II

\begin{tabular}{|c|c|c|c|c|}
\hline \multirow[t]{2}{*}{ No } & \multirow[t]{2}{*}{$\begin{array}{c}\text { Indikator } \\
\text { Kompetensi } \\
\text { Psikomotor }\end{array}$} & \multicolumn{2}{|c|}{$\begin{array}{l}\text { \% Kompetensi } \\
\text { yang Dicapai } \\
\text { pada Perte- } \\
\text { muan ke }\end{array}$} & \multirow{2}{*}{$\begin{array}{l}\text { \% Rata- } \\
\text { rata } \\
\text { Kompe- } \\
\text { tensi } \\
\text { Psikomo- } \\
\text { tor pada } \\
\text { Siklus I }\end{array}$} \\
\hline & & I & II & \\
\hline 1 & Ps. 1 & 86,0 & 91,4 & 88,7 \\
\hline 2 & Ps. 2 & 82,8 & 86,0 & 84,4 \\
\hline 3 & Ps. 3 & 78,5 & 80,6 & 79,6 \\
\hline & Rata-rata & 82,5 & 86,0 & 84,3 \\
\hline
\end{tabular}

Berdasarkan data hasil pengamatan kompetensi psikomotor siswa pada Tabel 5, untuk lebih jelasnya data tersebut disajikan dalam bentuk grafik seperti pada Gambar 4. 


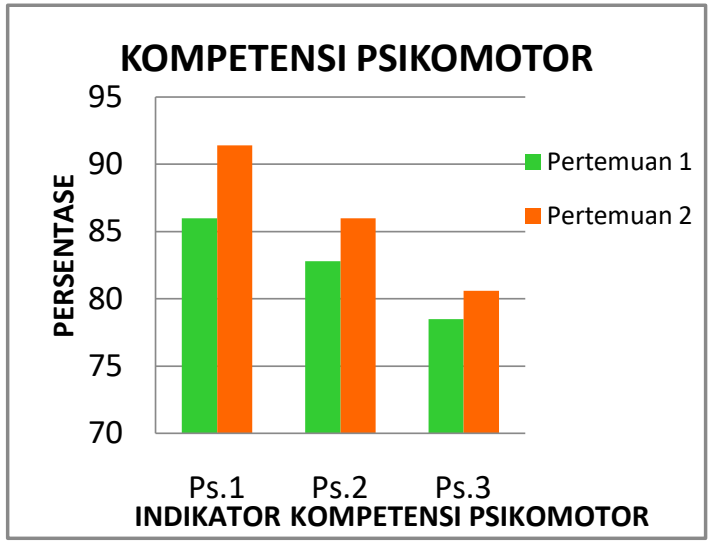

Gambar 4. Persentase Kompetensi Psikomotor Siswa Tiap Indikator pada Siklus II

Berdasarkan Tabel 5 dan Gambar 5 terlihat adanya peningkatan kompetensi siswa yang sangat bagus dari masing-masing indikator dari pertemuan 1 sampai pertemuan 2.

Data tentang kompetensi kognitif siswa pada siklus II diperoleh dengan mengadakan Ulangan Harian II berupa tes tertulis yang diikuti oleh 31 orang siswa dengan jumlah soal 20 butir berbentuk objektif tes.

Hasil nilai kompetensi kognitif pada siklus II dapat dilihat pada lampiran. Hasil analisis data secara ringkas dapat dilihat pada Tabel 6.

Tabel 6. Persentase Ketuntasan Kompetensi Kognitif dan Nilai Rata- rata Siswa pada siklus II

\begin{tabular}{ccccc}
\hline \multicolumn{2}{c}{$\begin{array}{c}\text { Siswa yang } \\
\text { Tuntas }\end{array}$} & \multicolumn{2}{c}{$\begin{array}{c}\text { Siswa yang } \\
\text { Tidak Tuntas }\end{array}$} & $\begin{array}{c}\text { Nilai } \\
\text { rata-rata }\end{array}$ \\
\hline $\mathrm{f}$ & $\%$ & $\mathrm{f}$ & $\%$ & \\
29 & 93,5 & 2 & 6,5 & 87,4 \\
\hline
\end{tabular}

Dari Tabel 6 dapat dilihat bahwa dari 31 orang siswa, 29 orang sudah tuntas atau mencapai KKM sedangkan 2 orang belum tuntas atau belum mencapai KKM. Ketuntasan secara klasikal adalah 93,5 \%, berarti secara klasikal siswa sudah tuntas.

\section{Pembahasan}

Berdasarkan hasil analisis kompetensi afektif siswa dari siklus I sampai siklus II dapat dijelaskan bahwa, indikator yang mengalami peningkatan paling sedikit adalah indikator kompetensi kerjasama sebesar 3,3\%, sedangkan indikator yang mengalami peningkatan yang paling tinggi adalah bertanya sebesar 16,65 \% . Sedikitnya peningkatan pada indikator kompetensi kerjasama disebabkan karena pada awal sampai akhir pembelajaran terlihat kerjasama siswa sudah baik, jadi peningkatan tidak terlihat secara signifikan. Sedangkan peningkatan pada kompetensi bertanya menunjukkan angka yang signifikan, hal ini disebabkan karena siswa sudah terlatih bertanya dengan kalimat yang sopan dan memahami materi yang akan ditanyakan pada kelompok lain. Untuk indikator menjawab juga terjadi peningkatan karena siswa juga sudah terlatih menjawab dengan lancar dan sopan. Secara umum terlihat adanya peningkatan kompetensi afektif siswa dari siklus I ke siklus II.

Berdasarkan hasil analisis kompetensi psikomotor siswa dari siklus I sampai siklus II dapat dijelaskan bahwa, indikator yang mengalami peningkatan paling sedikit adalah indikator mempresentasikan hasil diskusi dan paling tinggi peningkatannya adalah pada indikator mengumpulkan informasi dari berbagai buku sumber. Kecilnya peningkatan pada indikator mempresentasikan hasil diskusi disebabkan karena masih ada beberapa orang siswa yang masih ragu-ragu dan kurang percaya diri saat melakukan prsestasi sehingga terlihat kurang kompeten. Besarnya peningkatan pada indikator mengumpulkan informasi dari berbagai buku sumber karena siswa sudah mempunyai berbagai buku sumber dan siswa sudah mulai terbiasa mereorganisasikan tentang materi yang akan dibahas sehingga hasil kerjanya dapat dijalankan dengan tepat dan cepat.

Peningkatan kompetensi siswa secara menyeluruh terjadi karena pelaksanaan pembelajaran memberikan kesempatan lebih banyak kepada siswa untuk aktif secara fisik, mental dan emosional melalui kegiatan penyelidikan, diskusi kelompok atau melakukan presentasi kelompok. Hal ini sejalan dengan pendapat Bruner (Noeraida, 2016:9) yang mengatakan bahwa proses pembelajaran akan berjalan dengan baik dan kreatif jika guru memberikan kesempatan kepada siswa untuk menemukan suatu konsep, teori, aturan, atau pemahaman melalui contoh yang dijumpai dalam kehidupannya. Selanjutnya Irnawati(2016:4) menyatakan bahwa proses pembelajaran akan berjalan dengan baik apabila siswa banyak menggali informasi sendiri, menganalisa data, mempresentasikan serta memahami materi dengan generalisasi datanya. 


\section{KESIMPULAN}

Berdasarkan hasil penelitian dan pembahasan maka diperoleh kesimpulan: (1) kompetensi afektif pada siklus I dengan kategori baik dan pada siklus II yaitu dalam kategori amat baik, berarti terjadi peningkatan (2) terjadi peningkatan rata-rata kompetensi psikomotor pada siklus II jika dibandingkan dengan siklus I, dan (3) terjadi peningkatan ratarata ulangan harian siswa pada siklus II jika dibandingkan dengan siklus I. Jika dibandingkan dari nilai rata-rata sebelum penelitian dengan rata-rata setelah penelitian maka terjadi peningkatan. Berarti secara keseluruhan terjadi peningkatan kompetensi siswa dari siklus I ke siklus II pada materi Tata Surya dalam pembelajaran IPA kelas IX melalui model pembelajaran Discovery Learning.

Berdasarkan pada kesimpulan yang diuraikan dapat dikemukakan beberapa saran: (1) Guru IPA diharapkan dapat menerapkan model pembelajaran Discovery Learning pada pembelajaran karena dapat meningkatkan kompetensi siswa dalam pembelajaran IPA, (2) peneliti lain agar dapat melanjutkan atau melakukan penelitian serupa dengan memperbaiki beberapa kekurangan yang masih ada, sehingga timbul suatu keyakinan bahwa penerapan model pembelajaran Discovery Learning dapat meningkatkan kompetensi siswa dalam proses pembelajaran, (3) dalam menerapkan model pembelajaran Discovery Learning disarankan untuk mencermati waktu terutama dalam diskusi kelompok untuk memecahkan permasalahan dan melakukan presentasi.

\section{DAFTAR PUSTAKA}

Fadiawati, dkk. 2007. Performance Assesment Produk dan Keterampilan. Jakarta. UPI

Haryani, dkk. 2007. Assesmen Responden Terbatas dan Essay.Jakarta: UPI

Irnawati. 2016.Peningkatan Hasil Belajar Ekonomi Melalui Model Discovery Learning.Agam: Jurnal Pendidikan Agam

Kanginan. 2002. IPA Fisika kelas IX. Bandung: PT. Gelora Aksara Pratama

Kemdikbud. 2013. Materi Pelatihan Imple mentasi Kurikulum 2013. Jakarta: Badan PSDMPK-PMP

Maulana,dkk. 2016. Modul Guru Pembelajarn Kompetensi I. Jakarta: PPPPPTK IPA
Munandar. 2010. Mengembangkan Bakat dan Kreativitas Anak Sekolah. Jakarta: PT Gramedia Widiasarana Indonesia

Noeraida,dkk. 2016. Modul Guru Pembelajar Kompetensi D: Jakarta: PPPPPTK IPA

Sagala, S. 2003. Konsep dan Makna Pembelajaran. Bandung: Alpabeta

Trianto. 2010. Mendesain Model-model Pembelajaran Inovatif Progresif. Jakarta: Kencana Prenada Media Group.

Uno. 2012. Model Pembelajaran. Jakarta: PT. Bumi Aksara 